\title{
Making Organic Fertilizer Resistant to Bacterial Leaf Blight Disease for Grain Crops
}

\author{
Mohammad Rifki $^{1}$, Luqman Hanifianto ${ }^{1}$, Sri Rachmania Juliastuti ${ }^{1}$, Raden Darmawan ${ }^{1}$, and Nuniek Hendrianie ${ }^{1, *}$
}

Departement of ${ }^{1}$ Chemical Engineering Institut Teknologi Sepuluh Nopember, Kampus ITS Surabaya 60111, Indonesia

\begin{abstract}
Farmers too often use chemical fertilizers to help rice production, but in the long run fertilizer detrimental to land. Xanthomonas Oryzae Pv Oryzae (Xoo) is a microorganism that causes the disease of Bacterial Leaf Blight (BLB) in rice that harms farmers. Pseudomonas flourescens $(\mathrm{Pf})$ is potentially the controller of Xoo and Azotobacter chrococcum (Az) causing rice to be more resistant to disease so as to help reduce the impact of BLB on rice plants in the form of organic fertilizers. The purpose of this research is to utilize corn farm waste into organic fertilizer that is resistant to BLB plant disease (bacterial leaf blight) caused by Xanthomonas Oryzae microorganism. In this research will be made of organic fertilizer from corn farm waste using rotary drum composting method with the help of Bioactivator EM4, Pf and Az bacteria. The results of this study found that the best plant growth in the variable comparison of microorganisms Pseudomonas fluorecense: Azotobacter chroococum 1: 2 and urea. Plant growth on day 25 is higher $(32.8 \mathrm{~cm})$ than other variables and the number of grains is 80 .
\end{abstract}

\section{Introduction}

In the modern era like today the use of fertilizer has become the norm especially inorganic fertilizer to increase nutrient on soil .Many use of fertilizer very affect in agricultural progress in indonesia .Various companies fertilizer urea also increase production to meet agricultural needs in indonesia .But, the use of excessive fertilizer can have a negative impact on the ground and environment . This negative impact it should be stopped or at least reduced, because if they do not dismissed or reduced then as slowly so the structure of the soil be broken . [9]

Besides needs nutrient that must be fulfilled, to increase productivity of rice need to an increase in defense rice of a disease .A disease that there are often in rice is $\mathrm{BB}$ ( leave Blight ). $\mathrm{BB}$ disease caused by bacteria Xanthomonas oryzae.The bacteria is can infect of paddy starting from a nursery to harvest. Symptoms of disease $\mathrm{BB}$ in plants in seedling, usually characterized by color yellowing on the edge of a leaf that is not easily observed. Symptoms found in phase growth saplings until maturation phase is a symptom of blight until of a line yellowish on the leaves flag .

$\mathrm{BB}$ is among the top five malignancy both in the tropics and sub tropics. BB is dangerous not only his potential epidemic, but also his microbe can be transmitted by seeds and can survive in the seed for annuals . Even in india blight microbes can survive until 11 months. In indonesia $\mathrm{BB}$ is also one of the most important disease of rice plants, especially on of paddy fields . BB disease can reduce rice productivity to $60 \%$. [3]
Reduction of various businesses this disease have been conducted, among others by using synthetic chemical ingredients like benzoic acid and nitrites, nor the application of pesticides using basic antibiotic compounds ( asman , 1996 ) .The use of chemicals as fertilizer and pesticides and antibiotics in handling plant disease can cause resistance against bacteria, inflicting residue, and environmental pollution . [10]

Alternatives such as bio control application mikrob controller biodiversity antimikrob produce substance without pollute the environment . Bacteria capable of producing a metabolite compound that has an effect or bakteriostatik bakterisidal to hinder the growth of pathogenic bacteria .A genus of bacteria commonly used and yielding an astringent antimikrob bakteriosin is in the form of Bacillus sp [2]

According to [10], Pseudomonas aeruginosa, Pseudomonas fluorescens, Bacillus cereus, and Bacillus $s p$ Have good potential to inhibit pathogen bacterial growth of paddy xanthomonas oryzae . So breeding bacterium Pseudomonas aeruginosa on fertilizer will help improve defense of paddy against blight disease

\section{Experimental}

\subsection{Material}

Materials that used in this research are NB Liquid, Agricultural waste corn (Limbah pertanian jagung), bioactivator EM4, Azotobacter Chroococcum, Xanthomonas oryzae Pv Oryzae, Pseudomonas flourescens, and IR64 Rice.

\footnotetext{
*Corresponding author: nuniek@chem-eng.its.ac.id
} 


\subsection{Procedure}

\subsubsection{Microbe Preparations.}

Inoculum of Pseudomonas flourescens on Nutrient Broth Agar (NBA) media are propagated to the process of generation using scratch method with slant agar . Then moved in liquid media NB with the stab and incubation on the temperature 25 to $30{ }^{0} \mathrm{C}$. The same procedure was uses to treating inoculum of bacteria Azotobacter chroococcum and Xanthomonas oryzae pv oryzae.

\subsubsection{Composting Process.}

Before start composting process necessary analysis of the $\mathrm{N}, \mathrm{P}, \mathrm{K}, \mathrm{C}$, and the water content of on the agricultural waste corn. Then agricultural waste corn put into rotary drum composter with additional aktivator em4 and bacteria Azotobacter chrocooccum and Pseudomonas flourescens composed in accordance with a variable that set before. A rotary drum composter drained air about $141 /$ minutes using aerator to support the aerobic Process . Performed the measurement of temperature and $\mathrm{pH}$ once every day. during composting process the inside drums agitators rotated 3 times a day to compost mature, each rotated as many as 15 times. After compost formed then $\mathrm{N}, \mathrm{P}, \mathrm{K}, \mathrm{C}$ and water contents need to analiyzed.

\subsubsection{Test influence fertilizer to intensity attack blight in rice plant.}

For rice cultivation, prepared conducive land first and added water to increase moisture land .Land will be prepared size of less more 1 × 2 meters .Rice will be planted is rice has sowing first .Then adding organic fertilizers from the compost above to of paddy newly grown. After that, inject pathogen Xanthomonas oryzae pv oryzae with cliping method, as for step :

1. Bacteria pathogen prepared by putting it into a bottle

2. Dipping scissors into a solution that contains bacteria pathogen in bottles 1-2 minutes

3. Cut leaves rice with size 1- 2 inches. (IRRI, 2006)

After that, Measuring the intensity of blight desease everyday, and measurement of the height a plant any 2 days.

\section{Results and Discussion}

Table 1 is the result of analysis of $\mathrm{C}, \mathrm{N}, \mathrm{C} / \mathrm{N}$ ratio, $\mathrm{P}, \mathrm{K}$ of the raw material prior to the composting process. While Table 2 is the result of analysis of $\mathrm{C}, \mathrm{N}, \mathrm{C} / \mathrm{N}$ ratio, $\mathrm{P}, \mathrm{K}$ for variable microorganisms used in
Agricultural Waste Corn after the composting process is conducted for 15 days. From table 2 the look changes the levels of $\mathrm{C}, \mathrm{N}, \mathrm{c} / \mathrm{n}$ ratio, $\mathrm{P}$, and $\mathrm{K}$ on each variable after composting for 15 days.

Tabel 1. The Analysis Result Of C, N, C/n Ratio, P, K On Raw Materials

\begin{tabular}{|c|c|c|}
\hline Compound & $\begin{array}{c}\text { Agricultural } \\
\text { waste corn }\end{array}$ & $\begin{array}{c}\text { Standart quality of } \\
\text { organik fertilizer } \\
\text { according to } \\
\text { Permentan 2009 }\end{array}$ \\
\hline $\mathrm{C}$ & $27,6 \%$ & $>12 \%$ \\
\hline $\mathrm{N}$ & $0,03 \%$ & $<6 \%$ \\
\hline $\mathrm{C} / \mathrm{N}$ ratio & $920 \%$ & $15-25$ \\
\hline $\mathrm{P}$ & $1,42 \%$ & $<6 \%$ \\
\hline $\mathrm{K}$ & $1,08 \%$ & $<6 \%$ \\
\hline
\end{tabular}

Table 2. Analysis Result of C, N, c/n ratio, P, K After 15 days In Composting of agricultural Waste Corn

\begin{tabular}{|c|c|c|c|c|c|}
\hline \multirow{2}{*}{ Ratio Variabel } & \multicolumn{5}{|c|}{ Compound } \\
\hline & $\begin{array}{c}\mathrm{C} \\
(\%)\end{array}$ & $\begin{array}{c} \\
(\%)\end{array}$ & $\begin{array}{c}\mathrm{C} / \mathrm{N} \\
\text { Rasio }\end{array}$ & $\begin{array}{c}\mathbf{P} \\
(\%)\end{array}$ & $\begin{array}{c}K \\
(\%)\end{array}$ \\
\hline $\begin{array}{c}\text { Pseudomonas } \\
\text { flourescens } \\
\text { : Azotobacter } \\
\text { Chroococcum }(1: 1)\end{array}$ & 6,2 & 0,38 & 16,32 & 1,42 & 1,08 \\
\hline $\begin{array}{c}\text { Pseudomonas } \\
\text { flourescens } \\
\text { : Azotobacter } \\
\text { Chroococcum }(1: 2)\end{array}$ & 7,25 & 0,41 & 17,68 & 1,64 & 1,38 \\
\hline \multirow{2}{*}{ Ratio Variabel } & \multicolumn{5}{|c|}{ Compound } \\
\hline & $\begin{array}{c}C \\
(\%)\end{array}$ & $\begin{array}{c} \\
(\%)\end{array}$ & $\begin{array}{l}\text { C/N } \\
\text { Rasio }\end{array}$ & $\begin{array}{c}\mathbf{P} \\
(\%)\end{array}$ & $\begin{array}{c}K \\
(\%)\end{array}$ \\
\hline $\begin{array}{c}\text { Pseudomonas } \\
\text { flourescens } \\
\text { : Azotobacter } \\
\text { Chroococcum }(1: 3)\end{array}$ & 6,65 & 0,36 & 18,47 & 1,55 & 1,57 \\
\hline $\begin{array}{c}\text { Pseudomonas } \\
\text { flourescens } \\
\text { : Azotobacter } \\
\text { Chroococcum }(3: 1)\end{array}$ & 5,38 & 0,37 & 14,54 & 1,39 & 1,62 \\
\hline
\end{tabular}




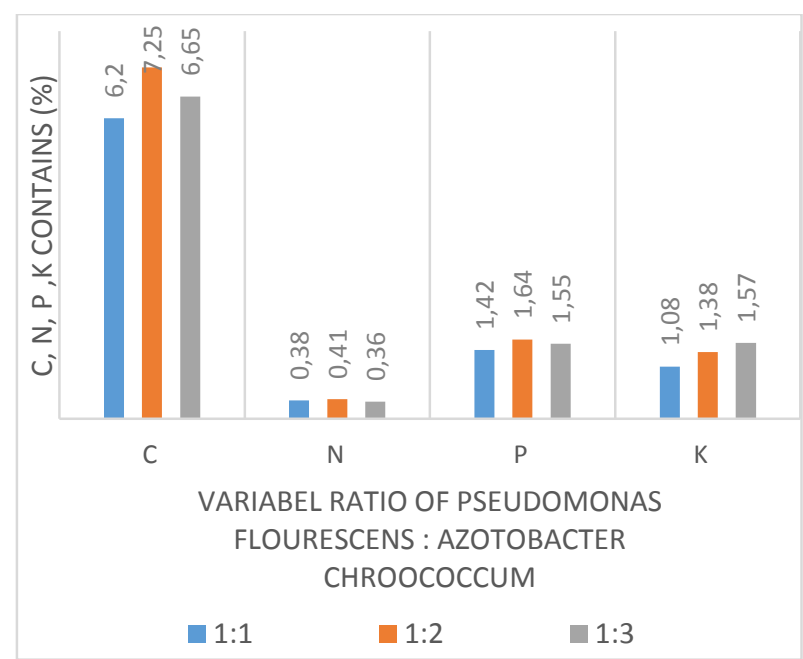

Fig. 1. $C, N, P, K$ contains of ratio Variabel 1:1, 1:2 and $1: 3$

Can be seen on a fig. 1 above that for element nitrogen and phospor, the largest located on the variables of 1: 2 . While on the variables of 1: 3 nitrogen and phospor contains is the smallest. This can be caused by decomposition microbes already suffering phase death. The more decomposition microbes used the fast too the process reshuffle done by microbes [7]. So that reshuffle to microbes variable 1: 3 reach maturity before 15 days and a decline $\mathrm{N}$ and $\mathrm{P}$ contains on the day to 15 .

Can be seen in the figur above that element of $\mathrm{N}, \mathrm{P}$, and $\mathrm{K}$ of the compost is increased on all variables. But the element of Corganik significant decrease, this indicates the elements of C-organic decomposes, it can be seen from the level of $\mathrm{C} / \mathrm{N}$ Ratio of compost, the lower the value of $\mathrm{c} / \mathrm{h}$ Ratio showed organic material already decomposes and almost become compost [6].

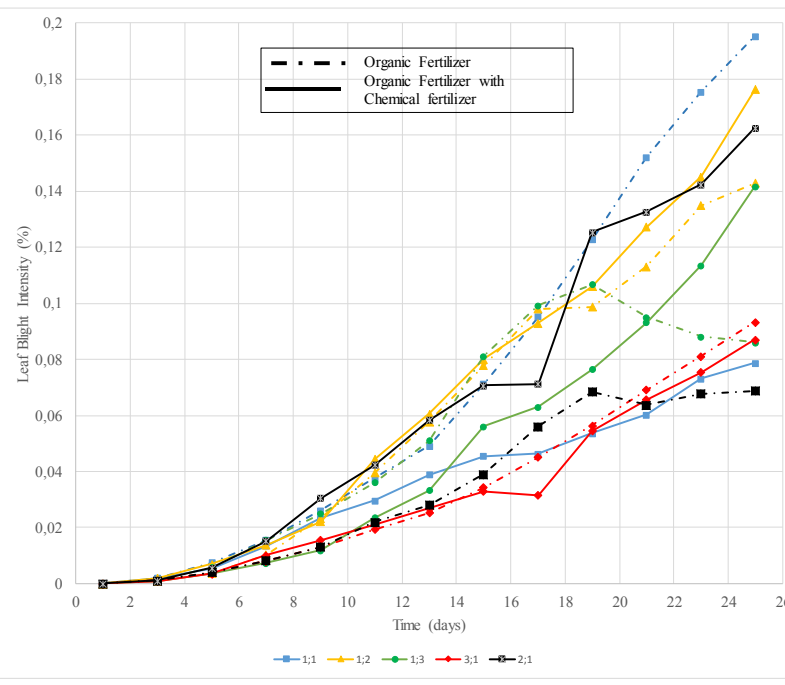

Fig. 2. Level infection of blight desease on each variabel

Fig 2 regarding the intensity of growth of Bacterial leaf blight disease (BB) without using urea addition for all variables. Can be seen fig 1 variable 1:1 is experiencing the highest disease growth compared to other variables. This can be caused by several factors such as the role of microorganisms Pseudomonas fluorecense not working properly, so that its growth is high.

As for the comparison of variable $3: 1$ the disease experience growth likely to slow, this is due to the role of microorganisms Pseudomonas fluorecense as an inhibitor of Bacterial leaf blight disease (HDB) can work well, because the awarding the more so that the intensity of the disease.

For comparison the variables $2: 1$ and 1:3 have the intensity of the ride starts the first day to day 18 of the observations, and then descends and nearly constant. This is due to Pseudomonas fluorecense not working on day 1 to 18 to the increase experienced also quite high. For comparison the variable 1:2 keeps rising from the first day until the end of the observation, but on the day of 18 observation experience slightly decreased until the end of the observation, it can be caused on day 18 microorganisms Pseudomonas fluorecense started to work properly.

While the attack blight to rice using additional urea.On a chart it has intesitas attack of illness a bad all the variables, this is because the urea can improve the disease in plants rice, because of an increasing the elements nitrogen on the ground can cause endurance plant against disease decline [8]

\section{Conclusion}

The best ratio variable of microorganisms Pseudomonas fluorecense : Azotobacter chroococum is on the ratio 1:2 and urea, evidenced by mild infections blight disease on day 15 that only $0.132 \%$ infected.

\section{References}

1. A. Asman, Prosiding Pertemuan Ilmiah Tahunan; Bogor, 13-14 Mar 1996". Bogor: Research Institute for Spice and Medicinal Crops, pp. 284290. Bogor (1996)

2. D. Bizani, A. Brandelli, A. Strain, J. Appl. Microbiol., 93: 512-519. (2002)

3. H. R. Hifni, \& M. Kardin. . Risalah Seminar Puslibangtan (1993)

4. IRRI..http://www.knowledgebank.irri.org/ricebree dingcourse/Breeding_for_disease_resistance_Blig ht.htm. 22.27 (2006)

5. IRRI.2013. 5th ed. Manilla : International Rice Research Institute (2013)

6. A. Ismayana, N. S. Indrasti \& N. Erica, Jurnal Bumi Lestari, 14 (1) (2014)

7. M. Mirwan, F. Rosariawari, Surabaya: Universitas Pembanguna Veteran (2010)

8. Suprihanto, A. Guswara \& Satoto. Subang: Balai Besar Penelitian Tanaman Padi (2008)

9. D. A. Suriadikarta, D. Setyorini. Bogor:Balai Penelitian Tanah (2005) 
10. Zuraidah. Banda Aceh : Jurnal Ilmiah Pendidikan Biologi, Biologi Edukasi, 5 (1) (2013) 